\title{
Grazing Effects on Snow Accumulation on Rough Fescue Grasslands
}

\author{
Walter D. Willms ${ }^{1}$ and David S. Chanasyk ${ }^{2}$ \\ Authors are ${ }^{1}$ Rangeland Ecologist, Agriculture and AgriFood Canada, PO Box 3000, Lethbridge, Alberta, Canada T1J 4B1; \\ and ${ }^{2}$ Professor, Department of Renewable Resources, University of Alberta, Edmonton, Alberta, Canada T6G $2 H 1$.
}

\begin{abstract}
Snow accumulation is an important process that defines the hydrological characteristics of grasslands and is mediated by vegetation structure. Grazing also affects those processes, but its relationship to snow accumulation is poorly understood. We conducted a study in the rough fescue grasslands in southwestern Alberta (lat $50^{\circ} 11^{\prime} 30^{\prime \prime} \mathrm{N}$, long $113^{\circ} 53^{\prime} 30^{\prime \prime} \mathrm{W}$ ) to determine the effect of grazing pressure on snow accumulation and its relationship with selected meteorological variables. Snow accumulation (mass per unit area) was measured throughout the winter from 1998 to 2004 within each of 3 watersheds that had different historical grazing pressures (high, moderate, and zero). In a second study, we examined the effect of artificially created patch sizes (0.5-, 1.0-, and 1.5-m diameter) on snow accumulation from 1998 to 2000 . The yearly average of the heavily and moderately grazed watersheds was about $42 \%$ and $20 \%$, respectively, less snow than the ungrazed watershed. Of the meteorological variables we tested, only average daily temperatures, average daily maximum temperatures, and snowfall were influenced by the watershed. Snowfall was about half as effective in predicting snow accumulation in the heavily grazed watershed as in the moderately grazed or ungrazed watersheds. Patch size was generally not effective, except at single observations in both 1998 and 1999 when the 1.0-m diameter patch captured the most snow mass per unit area. The ungrazed grassland captured a similar amount to that captured in the cut patches. The study indicates that increased grazing intensity reduces the ability of grasslands to capture snow.
\end{abstract}

\section{Resumen}

La acumulación de nieve es un proceso importante que define las características hidrológicas de los pastizales, y es mediado por la estructura de la vegetación. El apacentamiento también afecta esos procesos, pero su relación con la acumulación de nieve es pobremente entendida. Condujimos un estudio en los pastizales de "Rough fescue" del sudoeste de Alberta (latitud $50^{\circ} 11^{\prime} 30^{\prime \prime} \mathrm{N}$ y longitud $\left.113^{\circ} 53^{\prime} 30^{\prime \prime} \mathrm{W}\right)$ para determinar el efecto de la intensidad de apacentamiento en la acumulación de nieve y examinar su relación con variables meteorológicas seleccionadas. La acumulación de nieve (masa por unidad de área) se midió en todo el invierno, de 1998 a 2004, dentro de tres cuencas hidrológicas, las cuales tenían diferentes historiales de intensidad de apacentamiento (alta, moderada y cero). Usamos el análisis de varianza para probar el efecto de la intensidad de apacentamiento sobre el promedio anual de acumulación de nieve y análisis de regresión para relacionar la acumulación de nieve entre los tratamientos de apacentamiento con las variables meteorológicas. En un segundo estudio, de 1998 al 2000, examinamos el efecto del tamaño de parches creados artificialmente $(0.5,1.0$ y $1.5 \mathrm{~m}$ diámetro) sobre la acumulación de nieve. El promedio anual de nieve acumulada en las cuencas con apacentamiento alto y moderado fue aproximadamente $42(P<0.05)$ y $20 \%(P>0.05)$, respectivamente, menor que la acumulada en la cuenca sin apacentamiento. De las variables meteorológicas evaluadas, el apacentamiento influenció solo los efectos de la temperatura diaria máxima promedio y la caída de nieve. Respecto a la caída de nieve con la acumulación de ella, en la cuenca con intensidad alta de apacentamiento, fue casi la mitad de efectiva que en las cuencas con apacentamiento moderado o sin apacentamiento. El tamaño de parche generalmente no fue efectivo $(P>0.05)$, excepto en observaciones aisladas en 1998 y 1999, cuando el parche de $1.0 \mathrm{~m}$ de diámetro capturó más $(P<0.05)$ masa de nieve por unidad de área. El pastizal sin apacentamiento capturó una cantidad similar $(P>0.05)$ a la de los parches con corte. Este estudio indica que el incremento de la intensidad de apacentamiento reduce la habilidad del pastizal para capturar nieve.

Key Words: grazing pressure, artificial patches, meteorological variables, biomass

\section{INTRODUCTION}

Grazing affects the hydrological characteristics of grassland watersheds by increasing soil compaction, which reduces its infiltration capacity and promotes surface runoff (McCalla et al. 1984; Pluhar et al. 1987; Naeth and Chanasyk 1995), and by altering the vegetation structure, which influences water re-

Research was funded in part by the Alberta Agriculture Research Institute.

Correspondence: Walter D. Willms, Agriculture and AgriFood Canada, PO Box 3000, Lethbridge, Alberta, Canada T1J 4B1. Email: willms@agr.gc.ca

Manuscript received 10 June 2005; manuscript accepted 7 March 2006. tention and snow capture (Naeth and Chanasyk 1996). Naeth and Chanasyk (1996) reported greater snow depth in ungrazed sites and the least in very heavy grazed sites.

Topographic variability at various scales influences snow accumulation, which is the net result of snow capture and retention. Within a grassland watershed, snow tended to accumulate more at the midslope than at the upper slope (Naeth and Chanasyk 1996). At the microscale, topographic variability produced by furrows (Neff 1980), perennial grass stubble (Ries and Power 1981), or cereal stubble (Caprio et al. 1989; McGinn et al. 1994) improved soil moisture by capturing more snow than at more uniform sites. Grasslands exhibit structural variability produced by plants of different heights 
Table 1. Monthly mean daily air temperatures $\left({ }^{\circ} \mathrm{C}\right)$ and mean maximum (Max) and minimum (Min) daily air temperatures $\left({ }^{\circ} \mathrm{C}\right)$ over the study period at the study site.

\begin{tabular}{|c|c|c|c|c|c|c|c|c|c|c|c|c|c|c|c|}
\hline \multirow[b]{2}{*}{ Year } & \multicolumn{3}{|c|}{ January } & \multicolumn{3}{|c|}{ February } & \multicolumn{3}{|c|}{ March } & \multicolumn{3}{|c|}{ April } & \multicolumn{3}{|c|}{ May } \\
\hline & Mean & $\operatorname{Max}$ & Min & Mean & $\operatorname{Max}$ & Min & Mean & $\operatorname{Max}$ & Min & Mean & Max & Min & Mean & $\operatorname{Max}$ & Min \\
\hline 1998 & -8.4 & -3.8 & -12.9 & 0.3 & 5.2 & -4.5 & -3.0 & 1.1 & -7.1 & 6.0 & 10.8 & 1.2 & 11.6 & 16.8 & 6.4 \\
\hline 1999 & -4.9 & 0.3 & -10.0 & 0.0 & 4.3 & -4.4 & 0.7 & 5.2 & -3.9 & 4.3 & 9.4 & -0.8 & 7.7 & 13.1 & 2.2 \\
\hline 2000 & -5.8 & -0.9 & -10.7 & -3.0 & 1.3 & -7.3 & -0.3 & 3.8 & -4.3 & 4.3 & 10.1 & -1.5 & 8.8 & 14.2 & 3.4 \\
\hline 2001 & 0.9 & 4.9 & -3.0 & -8.3 & -3.4 & -13.1 & 0.1 & 4.8 & -4.6 & 3.2 & 7.5 & -1.0 & 11.0 & 17.1 & 4.9 \\
\hline 2002 & -4.3 & 0.3 & -8.9 & -2.1 & 2.3 & -6.5 & -9.9 & -4.5 & -15.2 & -0.1 & 4.4 & -4.6 & 6.3 & 11.0 & 1.5 \\
\hline 2003 & -3.2 & 2.6 & -9.0 & -4.7 & -0.3 & -9.2 & -2.8 & 2.8 & -8.4 & 3.9 & 7.8 & 0.0 & 8.1 & 12.6 & 3.7 \\
\hline 2004 & -8.8 & -4.9 & -12.6 & -0.3 & 4.4 & -5.0 & 2.2 & 7.6 & -3.3 & 6.2 & 11.7 & 0.6 & 7.1 & 11.4 & 2.5 \\
\hline
\end{tabular}

and through disturbances such as fire and, more commonly, livestock grazing.

Trampling and grazing by livestock induces structural variability, which can lead to heavily grazed and lightly grazed patches. Grazing pressure and stock density, which influence livestock distribution, dictate patch size. Therefore, high grazing pressure tends to increase the size of heavily grazed patches, whereas increasing stock density will tend to distribute animals more uniformly. Patchiness produced by grazing will persist providing that the grazing regime is maintained (Willms et al. 1988). Therefore, grazing management influences both herbage mass and its structural distribution in grassland.

The effect of vegetation on snow accumulation becomes much more important in areas subject to Chinook winds such as those experienced in southwestern Alberta. Because very little information exists on the role of vegetation structure on snow accumulation, we conducted a study to determine the effect of grazing pressure on snow accumulation and examined its relationship with selected meteorological variables. We also examined the effects of patch size on snow accumulation. The hypotheses tested were that heavy grazing pressure reduced snow capture and that small patches were more effective in capturing snow than large patches. We based our estimates on snow mass rather than snow depth, which can be confounded by the underlying vegetation on which snow may be perched.

\section{MATERIALS AND METHODS}

\section{Study Site Description}

The study was conducted at the Agriculture and AgriFood Canada Range Substation in the rough fescue grasslands of southwestern Alberta (lat $50^{\circ} 11^{\prime} 30^{\prime \prime} \mathrm{N}$, long $113^{\circ} 53^{\prime} 30^{\prime \prime} \mathrm{W}$ ).
This site is characterized by hilly topography with slopes ranging from $18 \%$ to $37 \%$ and ranging in elevation from 1280 to $1420 \mathrm{~m}$ above sea level. Average annual precipitation was about $405 \mathrm{~mm}$, with $35 \%$ of it occurring as snow. The soils are classified as Orthic Black Chemozemic (Typic Haplustoll) developed on till overlying sandstone (Dormaar et al. 1990) and having loam to clay loam texture. Rough fescue (Festuca campestris Rydb.) is the dominant plant species and is commonly associated with Parry's oatgrass (Danthonia parryi Scribn.). Grazing reduces the basal area of rough fescue, which allows the expansion of short grasses and forbs (Willms et al. 1985). We installed a meteorological station at the substation with sensors to measure air temperature, precipitation, and wind variables. We obtained average monthly minimum, maximum, and mean daily air temperatures (Table 1), as well as total daily snowfall and average daily wind speeds (Table 2). Air temperature was measured using a Vaisala HMP35C probe (Vaisala Oyj, Vantaa, Finland) inside a Stevenson screen mounted at 1.4-m height. Wind speed and direction were measured with a RM Young 05103-10 (R.M. Young Co., Traverse City, MI) sensor on a tower at $10 \mathrm{~m}$. Rainfall was measured with a Texas Instruments TE525M (Texas Instruments, Dallas, TX) tipping bucket rain gauge, and both rain and snowfall were measured with an all-season weighing Fisher Porter (Belfort Instrument Company, Baltimore, MD) precipitation gauge.

\section{Watershed Study}

We selected 3 watersheds in 1996 within paddocks that had been subject to different cattle grazing management. One paddock had been exposed to moderate $\left(2.4\right.$ animal unit mo $\left.\cdot \mathrm{ha}^{-1}\right)$

Table 2. Total monthly snowfall and mean monthly wind speed over the study period at the study site.

\begin{tabular}{|c|c|c|c|c|c|c|c|c|c|c|}
\hline \multirow[b]{2}{*}{ Year } & \multicolumn{5}{|c|}{ Total snowfall (cm) } & \multicolumn{5}{|c|}{ Mean wind speed $\left(\mathrm{km} \cdot \mathrm{h}^{-1}\right)$} \\
\hline & January & February & March & April & May & January & February & March & April & May \\
\hline 1998 & 10.2 & 4.0 & 33.3 & 7.5 & 0.0 & 13.0 & 14.3 & 13.7 & 15.1 & 16.5 \\
\hline 1999 & 4.6 & 2.5 & 8.8 & 39.0 & 6.4 & 18.8 & 24.5 & 17.0 & 16.6 & 18.5 \\
\hline 2000 & 8.5 & 10.4 & 19.1 & 13.8 & 0.0 & 12.8 & 14.9 & 16.5 & 17.7 & 18.0 \\
\hline 2001 & 9.1 & 4.7 & 5.9 & 27.9 & 0.0 & 16.2 & 13.4 & 18.3 & 20.8 & 21.3 \\
\hline 2002 & 15.3 & 11.9 & 17.3 & 24.0 & 58.7 & 20.0 & 20.7 & 13.5 & 18.6 & 19.4 \\
\hline 2003 & 6.0 & 12.5 & 24.7 & 18.5 & 17.0 & 17.1 & 12.1 & 18.6 & 15.2 & 17.6 \\
\hline 2004 & 8.7 & 0.8 & 8.6 & 4.7 & 23.3 & 15.0 & 13.0 & 21.0 & 16.1 & 15.9 \\
\hline
\end{tabular}


grazing pressure, and a second to heavy (4.8 animal unit $\mathrm{mo} \cdot \mathrm{ha}^{-1}$ ) grazing pressure, since 1949 that removed about $60 \%$ and $80 \%$, respectively, of above-ground net primary production (Willms et al. 1985). A third paddock had been ungrazed for most of that time. The watersheds were approximately $100 \mathrm{~m}$ wide and 180-250 $\mathrm{m}$ long. The 2 grazed watersheds were contiguous, and the ungrazed control was located approximately $1 \mathrm{~km}$ to the west. All 3 watersheds faced east, had average slopes of $18 \%$ to $20 \%$, and were at similar elevations and positions on the slope in relation to the crest.

\section{Herbage Biomass}

Two parallel transects, each having 6 equidistant sampling points, were installed $40 \mathrm{~m}$ apart and about $30 \mathrm{~m}$ from the sides of each watershed. The transects extended from the upper to lower slope positions within the watershed. Herbage biomass components were estimated $0.5 \mathrm{~m}$ from the center in 1 of 3 cardinal directions $(\mathrm{S}, \mathrm{E}$, and $\mathrm{W})$ at the completion of grazing in November of 1998, 1999, and 2000. Standing litter (dead leaf and stem herbage attached at the plant base), fallen litter (coarse detached leaf and stem herbage; $>2 \mathrm{~cm}$ in length), and fine litter (fragmented/decomposed leaf and stem herbage; $<2$ $\mathrm{cm}$ length) were harvested, respectively, from $50 \times 50 \mathrm{~cm}$ and $50 \times 20 \mathrm{~cm}$ quadrats and circular plots $(10.5-\mathrm{cm}$ diameter $)$ in a hierarchical manner of superimposed plots in order from large to small. Fine litter was sampled by extracting a core to a depth of $10 \mathrm{~cm}$ using a sod corer. The core was then dissected at the litter-soil interface, the soil discarded, and the litter fraction floated in water to remove attached soil. All litter components were dried to a constant weight and their mass determined.

In each $50 \times 50 \mathrm{~cm}$ quadrat, we also estimated the average height of standing litter. This was determined before harvest as the mean of maximum litter height taken at 3 randomly selected points in the quadrat.

\section{Snow Accumulation}

We measured snow depth using a ruler at each biomass sampling point at about weekly intervals, while snow was present in all watersheds, in the winters from 1997-1998 to 2003-2004 (hereafter referenced as 1998-2004, respectively). The ruler was inserted perpendicularly to the slope and snow depth read to the nearest $1 \mathrm{~cm}$. The measurements were made with the observer approaching the sampling area perpendicularly to the transect and prevailing wind, standing at least $75 \mathrm{~cm}$ from the sampling point, and reaching into the sampling area to insert the ruler. The earliest and latest measurements during the 7-year study were 8 January and 9 May, respectively, and the total numbers of measurements in each year of the study (1998-2004) were 9, 5, 10, 7, 11, 4, and 3, respectively. Snow density $\left(\mathrm{g} \cdot \mathrm{cm}^{-3}\right)$ was determined at each visit by extracting a $7-\mathrm{cm}$ diameter snow core to a measured depth near each sampling point on 1 transect of each treatment, placing the snow in watertight plastic bags, and weighing. The density estimate of each sampling point was also applied to the paired point in the second transect, which was within $40 \mathrm{~m}$ of the first transect and at an equivalent slope position. Water-equivalent snow mass (WESM; $\mathrm{kg} \cdot \mathrm{m}^{-2}$ ) for each sampling point was calculated as:

$$
\begin{aligned}
\text { WESM }= & \text { snow density }\left(\frac{\text { mass }(\mathrm{g})}{\operatorname{volume}\left(\mathrm{cm}^{3}\right)}\right) \times \\
& \text { snow depth }(\mathrm{cm}) \times\left(\frac{10000 \mathrm{~cm}^{2}}{\mathrm{~m}^{2}} \times \frac{1 \mathrm{~kg}}{1000 \mathrm{~g}}\right) .
\end{aligned}
$$

\section{Patch Size}

In a second study, we tested the effect of patch size on snow capture and retention over 3 winters in 1998, 1999, and 2000. The study was conducted in an ungrazed exclosure on level terrain in good-condition rough fescue grassland. In the first winter (1998), we established a randomized complete block experiment with 3 circular patch sizes and 5 blocks. We created patches (0.5-, 1.0-, and $1.5-\mathrm{m}$ diameter) by cutting and removing the vegetation to about $3 \mathrm{~cm}$ from ground level. The patch sizes chosen for investigation represented areas that might result under light to moderate season-long grazing pressure in the fescue grassland, and were sufficiently small to study. We also expected that any response to incremental patch size would be greatest at the small scale. The blocks were spaced about $50 \mathrm{~m}$ apart, and the patches were spaced $2 \mathrm{~m}$ apart and oriented in a north-south direction to minimize interaction among treatments because the prevailing wind tended to be from the west. In 1999 and 2000, the trials were established in new locations but in a comparable plant community. Patch size and orientation were the same as in the first year but only 3 blocks were established. In addition, each patch was paired with an uncut control located $2 \mathrm{~m}$ west of the cut patch, which was in the direction of the prevailing wind to avoid influence by the cut patch.

We used a ruler to measure snow depth at about weekly intervals at systematically located sampling points along the plot circumference, on a concentric circle within the plot that had half the diameter of the plot, and at the plot center. This design ensured that the entire plot was sampled and that variation in snow distribution would be detected. The number of sampling points was 17,17 , and 41 in the $0.5-, 1.0-$, and 1.5-m diameter patches, respectively. Average snow depth was determined by a weighted average of each sampling point. The basis for weighting was the area each point represented in the plot. Snow depth was converted to a water-equivalent snow mass, as described above, and reported for a $1-\mathrm{m}^{2}$ standard area. Plant height was measured at 8,8 , and 16 equally spaced points on the perimeter of the $0.5-, 1.0-$, and $1.5-\mathrm{m}$ diameter plots, respectively.

\section{Statistical Analyses}

The 3 watershed treatments were spatially unreplicated but were measured repeatedly over 3 or 7 years for vegetation characteristics or snow mass, respectively. All analyses of variance (ANOVA; Mixed Procedure; SAS 1999) were made with the assumption that year was a random variable. Mean litter biomass and litter height were analyzed for each grazing treatment $(n=3)$ and tested against the year $(n=3) \times$ grazing treatment error term. We also calculated the coefficient of variation $(\mathrm{CV})$ of standing litter mass and height as an expression of their heterogeneity within each watershed. Snow accumulation was analyzed by grazing treatment $(n=3)$ and slope location $(n=6)$ within grazing treatment. 
Table 3. Average biomass of 3 litter classes and height of standing litter estimated in 1998, 1999, and 2000 at the completion of grazing by cattle in 3 fescue grassland watersheds having different historical stocking rates. Within a column, means with the same letter are not different $(P>0.05)$.

\begin{tabular}{|c|c|c|c|c|c|c|}
\hline \multirow[b]{3}{*}{ Grazing history ${ }^{1}$} & \multicolumn{3}{|c|}{ Litter biomass $\left(\mathrm{g} \cdot \mathrm{m}^{-2}\right)$} & \multirow[b]{3}{*}{ Standing litter height $(\mathrm{cm})$} & & \\
\hline & \multirow[b]{2}{*}{ Attached standing } & \multicolumn{2}{|c|}{ Fallen fragmented ${ }^{2}$} & & \multicolumn{2}{|c|}{ Average $\mathrm{CV}^{3}(\%)$} \\
\hline & & Coarse & Fine & & Attached standing mass & Standing litter height \\
\hline Ungrazed & $334 \mathrm{~b}$ & $496 \mathrm{~b}$ & $378 \mathrm{~b}$ & $39.6 \mathrm{~b}$ & $23 \mathrm{a}$ & $16 \mathrm{a}$ \\
\hline Moderate & $68 \mathrm{a}$ & $57 \mathrm{a}$ & $72 \mathrm{a}$ & $4.6 \mathrm{a}$ & $64 \mathrm{~b}$ & $48 \mathrm{~b}$ \\
\hline Heavy & $45 \mathrm{a}$ & $54 \mathrm{a}$ & $116 \mathrm{a}$ & $3.2 \mathrm{a}$ & $30 \mathrm{a}$ & $25 \mathrm{a}$ \\
\hline Probability & $<0.001$ & $<0.001$ & 0.016 & $<0.001$ & 0.003 & 0.002 \\
\hline
\end{tabular}

${ }^{1}$ Fifty-year history, Ungrazed indicates 0 to light stocking rate; moderate, 3.6 animal unit $\mathrm{mo} \cdot$ ha $^{-1}$; heavy, 4.8 animal unit $\mathrm{mo} \cdot$ ha $^{-1}$.

${ }^{2}$ Litter that is detached from the plant and separated into coarse $(>2 \mathrm{~cm}$ in length) and fine ( $<2 \mathrm{~cm}$ in length).

${ }^{3}$ Coefficient of variation. The CVs were determined from 12 samples taken in each watershed and averaged over 3 years.

For this analysis, year $(n=7)$ was assumed to be a random factor in the ANOVA to assess the effects of the grazing treatment $(n=3)$ and slope location $(n=6)$ within the watershed on snow accumulation. Slope locations were nested within grazing treatment and analyzed with a repeated statement (SAS 1999). ANOVA was applied on the average of all measurements made within a year at each slope location. Before being analyzed, the residual variances of all data were tested for normality with the Shapiro-Wilk test, the Kolmogorov-Smirnov test, the Anderson-Darling test, and the Cramér-von Mises test using the Univariate procedure (SAS 1999). As a result of these tests, transformations were not required for any analyses.

We also used multiple regression analyses using stepwise selection (Regression Procedure; SAS 1999) to determine the effect of selected meteorological variables on snow accumulation as affected by grazing treatment. For these analyses, we used average air temperature (daily maximum and daily average), average daily peak wind speed and wind direction, and total snowfall for each measurement interval. We analyzed the data in 2 steps. In the first, we examined the interaction of each meteorological variable with grazing treatment on snow accumulation to identify the variables whose effect was influenced $(P<0.05)$ by grazing. Snow mass at the beginning of each measurement interval was included in the multiple regression analysis, which adjusted for differences among

Table 4. Average snow accumulation (water equivalent) in relation to grazing treatment and location ${ }^{1}$ within the watershed over a $7-y$ period from 1998 to 2004.

\begin{tabular}{|c|c|c|c|c|}
\hline \multirow[b]{2}{*}{ Location } & \multicolumn{3}{|c|}{ Grazing treatment } & \multirow[b]{2}{*}{ Location means } \\
\hline & Ungrazed & Moderate & Heavy & \\
\hline & \multicolumn{4}{|c|}{ 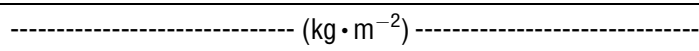 } \\
\hline 1 (Top) & 16.4 & 19.1 & 12.3 & 16.0 \\
\hline 2 & 18.5 & 19.7 & 11.2 & 16.4 \\
\hline 3 & 22.0 & 16.5 & 17.3 & 18.6 \\
\hline 4 & 24.5 & 19.6 & 13.4 & 19.2 \\
\hline 5 & 27.7 & 28.2 & 18.6 & 24.8 \\
\hline 6 (Bottom) & 44.0 & 19.8 & 16.7 & 26.8 \\
\hline Mean $^{2}$ & $25.5 \mathrm{~b}$ & $20.5 a b$ & $14.9 \mathrm{a}$ & 20.3 \\
\hline SEM & & 4.0 & & 4.4 \\
\hline Probability & & 0.037 & & 0.633 \\
\hline
\end{tabular}

${ }^{1}$ Interaction of grazing treatment and slope location is not significant $(P=0.095)$

${ }^{2}$ Means having the same letter are not different $(P>0.05)$. treatments and allowed all measurements to be pooled across and within years in a single analysis. In the second analysis by grazing treatment, we included only those meteorological variables that had a significant $(P<0.05)$ interaction in the previous analysis. The purpose of the first analysis was to identify the weather variables that were influenced by grazing, and the purpose of the second analysis was to determine the relationship of the variables to snow accumulation for each treatment.

ANOVA (Mixed Procedure; SAS 1999) was used to analyze the effect of patch size on snow accumulation for each measurement date and for average snow accumulation measured in each winter. In 1998, treatment (patch size; $n=3$ ) was tested with the replicate $(n=5) \times$ treatment error term. In both 1999 and 2000, the snow mass estimates from the uncut patch were averaged and weighted (weight $=3$ ) in a test of the treatment $(n=4)$ with the treatment $\times$ replicate $(n=3)$ error term.

\section{RESULTS}

\section{Herbage Biomass on Watersheds}

The mass of all herbage components and height of standing litter were greater $(P<0.01)$ in the ungrazed than in the grazed watersheds (Table 3 ). Mass of all herbage components and height of standing litter were similar $(P>0.05)$ across the 2 grazed watersheds, but the CVs of both attached standing mass and height was about twice as great $(P<0.01)$ in the moderately grazed watershed than in either the ungrazed or the heavily grazed watershed (Table 3 ).

\section{Grazing Effects on Snow Accumulation in Watersheds}

Snow accumulation was not affected $(P=0.633)$ by slope location within the watersheds, and the effect of slope location on snow accumulation was not influenced by treatment $(P=0.095$; Table 4). However, snow accumulation was different $(P=0.037)$ among the watersheds. Snow accumulation in the heavily and moderately grazed watersheds was about $42 \%$ and $20 \%$ less, respectively, than in the ungrazed watershed (Table 4).

The effects of average daily air temperature, average daily maximum air temperature, and snowfall on snow accumulation were different $(P<0.05)$ among the grazing treatments (Table 5). Within a watershed, only average daily maximum 
Table 5. Multiple regression analyses on the effects of selected meteorological variables on snow accumulation in relation to grazing treatment, with analyses based on observation periods over $7 \mathrm{y}$ in the rough fescue grasslands.

\begin{tabular}{|c|c|c|c|c|}
\hline \multirow[b]{2}{*}{ Variable } & \multirow[b]{2}{*}{ Grazing treatment interaction } & \multicolumn{3}{|c|}{ Watershed (grazing treatment) } \\
\hline & & Ungrazed & Moderate & Heavy \\
\hline & & \multicolumn{3}{|c|}{ - } \\
\hline Mean daily temperature $\left({ }^{\circ} \mathrm{C}\right)^{2}$ & 0.001 & - & - & - \\
\hline Mean daily maximum temperature $\left({ }^{\circ} \mathrm{C}\right)$ & $<0.001$ & $-1.17(0.32)$ & $-1.10(0.33)$ & $-1.03(0.24)$ \\
\hline Snowfall (cm) & $<0.001$ & $0.67(0.18)$ & $0.64(0.19)$ & $0.33(0.14)$ \\
\hline Mean daily maximum wind $\left(\mathrm{km} \cdot \mathrm{h}^{-1}\right)^{2}$ & $>0.05$ & - & - & - \\
\hline Model $R^{2}$ & 0.56 & 0.54 & 0.55 & 0.59 \\
\hline
\end{tabular}

${ }^{1}$ Not tested for grazing interaction.

${ }^{2}$ Variable did not contribute significantly $(P<0.05)$ to the model.

temperature and snowfall predicted $(P<0.05)$ snow accumulation. Snow accumulation was least responsive to average daily maximum temperature and snowfall in the heavily grazed watershed compared to the ungrazed or moderately grazed watersheds (Table 5).

\section{Patch Effects on Snow Accumulation}

Average snow accumulation was similar $(P>0.05)$ among patch sizes ranging from 0.5 to $1.5 \mathrm{~m}$ in diameter in any year (Table 6). However, effects were detected $(P<0.05)$ during single observations in both 1998 and 1999, when the midsized patch $(1.0-\mathrm{m}$ diameter) yielded the greatest amount of snow on a unit area basis. The uncut control yielded similar $(P>0.05)$ snow mass to the cut patches in 1999 and 2000, which were the only years it was measured (Table 6). The height of vegetation on the border of the cut patches was similar $(P>0.05)$ among treatments in any year and average heights were $14.2,14.9$, and $9.8 \mathrm{~cm}$ in 1998, 1999, and 2000, respectively (Table 6).

\section{DISCUSSION}

The effect of snow accumulation in relation to grazing intensity was examined in a spatially unreplicated experiment that constrains the scope of our interpretation to the specific conditions of each watershed and our ability to generalize to a broader landscape. Nevertheless, the watersheds of the study had a common aspect with similar slopes and positions on the slope, and the primary difference was grazing pressure. Although the treatments were not spatially replicated to capture meteorological variation, the watersheds were in close proximity to one another and observations were made over 7 years, which would account for such variability. Therefore, we believe our observations were an accurate representation of the grazing effect on snow accumulation on east-facing slopes with an $18 \%$ to $20 \%$ gradient.

Snow accumulation in the watersheds (Table 4) seemed to be related to both herbage mass and heterogeneity as expressed by the CV (Table 3). This inference is supported by the observation that the ungrazed watershed had about 5 and 7.5 times more standing herbage than the moderately and heavily grazed watersheds, respectively, but a CV that was only 0.36 and 0.77 times that of the same watersheds, respectively. If snow accumulation were dictated by herbage mass alone, then the moderately grazed watershed would have snow accumulation that was nearer to that of the heavily grazed watershed. However, the moderately grazed watershed yielded $37 \%$ more snow mass

Table 6. Average snow accumulation (water equivalent) in relation to patch size in $3 \mathrm{y}$, and individual observations within the year when treatment effects were significant $(P<0.05)$; and plant height on the patch perimeter or within uncut plots.

\begin{tabular}{|c|c|c|c|c|c|c|c|c|}
\hline \multirow[b]{4}{*}{ No. observations } & \multicolumn{5}{|c|}{ Snow accumulation $\left(\mathrm{kg} \cdot \mathrm{m}^{-2}\right)$} & \multicolumn{3}{|c|}{ Plant height $(\mathrm{cm})$} \\
\hline & \multicolumn{2}{|c|}{1998} & \multicolumn{2}{|c|}{1999} & \multirow{2}{*}{$\frac{2000}{\text { Mean }}$} & \multirow{2}{*}{$\frac{1998}{18 \text { November }}$} & \multirow{2}{*}{$\frac{1999}{13 \text { November }}$} & \multirow{2}{*}{$\frac{2000}{24 \text { November }}$} \\
\hline & 13 January & Mean & 11 January & Mean & & & & \\
\hline & 1 & 3 & 1 & 7 & 10 & 5 & 3 & 3 \\
\hline \multicolumn{9}{|l|}{ Patch size } \\
\hline 0 (Uncut) $)^{1}$ & - & - & $29.7 \mathrm{ab}$ & 14.3 & 9.3 & - & 18.9 & 12.8 \\
\hline $0.5 \mathrm{~m}$ & $11.8 a^{2}$ & 15.8 & $21.1 \mathrm{a}$ & 13.8 & 9.7 & 13.5 & 16.9 & 9.4 \\
\hline $1.0 \mathrm{~m}$ & $18.7 \mathrm{~b}$ & 16.5 & $42.2 \mathrm{~b}$ & 21.1 & 9.1 & 14.8 & 15.4 & 11.9 \\
\hline $1.5 \mathrm{~m}$ & $16.7 \mathrm{a}$ & 16.4 & $23.6 \mathrm{a}$ & 13.9 & 9.7 & 14.4 & 12.6 & 8.1 \\
\hline SEM & 1.4 & 2.8 & 4.4 & 2.1 & 0.7 & 0.7 & 1.4 & 1.3 \\
\hline \multicolumn{9}{|l|}{ Effects } \\
\hline Treatment & 0.025 & 0.983 & 0.030 & 0.128 & 0.906 & 0.506 & 0.060 & 0.106 \\
\hline
\end{tabular}

${ }^{1}$ Paired control plots located $2 \mathrm{~m}$ west of the cut plots.

${ }^{2}$ Means in column having the same letter are not different $(P<0.05)$. 
than the heavily grazed watershed but only about $20 \%$ less than the ungrazed watershed (Table 4). Therefore, grassland heterogeneity appeared to be a contributing factor to snow accumulation.

Further insight into the process of snow accumulation might be inferred from its relationship to average daily maximum air temperature and snowfall within grazing treatment (Table 5). According to the results, snowfall was only about half as effective in contributing to snow accumulation in the heavily grazed watershed as in the ungrazed or moderately grazed watersheds. The smaller contribution to snow accumulation is likely the result of less snow retention and greater redistribution by wind. The greater response to average daily maximum air temperature in the heavily grazed watershed is not obvious because exposure of the snow surface would be equivalent or perhaps less where litter provided shading. However, litter has a much lower albedo than snow, which would increase its temperature and that of the surrounding environment, thus increasing ablation.

The effectiveness of patch size was inconsistent but appeared to be dependent on its size and the height of vegetation (Table 6). A patch size of $1.0-\mathrm{m}$ diameter appeared to be the most effective in 1998 and 1999, when it accumulated the most snow mass during 1 observation period out of a total of 10 . The lack of response in 2000 may be partly the result of shorter vegetation, which is less effective in capturing snow than taller vegetation, as demonstrated by stubble heights of perennial grasses (Ries and Power 1981).

Properly managed grazing should not impair the snowretention properties of the rough fescue grasslands, because cut patches captured the same snow mass as adjacent uncut sites. However, heavy grazing pressure, which produces large overgrazed patches, reduced snow accumulation in the watersheds (Table 4), and it is uncertain how large an overgrazed patch must be before it functions like our heavily grazed watershed. The optimal size for snow capture appears to be quite small (about 1-m diameter) but natural heterogeneity produced by plants of different sizes would also enhance the process. Therefore, grazing systems that tend to concentrate animals and increase the uniformity of their distribution are also likely to reduce heterogeneity of plant height and thus impair snow capture.

\section{MANAGEMENT IMPLICATIONS}

Snow capture is one of the important processes that define the hydrological characteristics of a site. However, snow capture can be impaired by livestock grazing, which removes herbage litter and reduces heterogeneity. Undoubtedly, the effect that grazing has on watershed qualities will depend on their pregrazed structure and the type of grazing management. Our evidence suggests that grazing management is unlikely to improve snow capture in rough fescue grasslands that are in good condition, but it is possible to maintain snow capture at par with ungrazed grassland. Therefore, the objective of grazing management should be to minimize the impact on hydrological function through judicious use of grazing management.

\section{ACKNOWLEDGMENTS}

We gratefully acknowledge the assistance of Brian Handerek and Albert Middleton in developing the sampling technique and making snow measurements.

\section{LITERATURE CITED}

Caprio, J. M., G. K. Grunwald, and R. D. Snyder. 1989. Conservation and storage of snowmelt in stubble land and fallow under alternate fallow-strip cropping management in Montana. Agricultural and Forest Meteorology 45:265-279.

Dormaar J. F., AND W. D. Willms. 1990. Sustainable production from rough fescue grasslands. Journal of Soil and Water Conservation 45:137-140.

McCalla, G. R., II, W. H. Blackburn, and L. B. Merrill. 1984. Effects of livestock grazing on infiltration rates, Edwards Plateau of Texas. Journal of Range Management 37:265-269.

McGinn, S. M., B. W. Grace, and C. W. Lindwall. 1994. Tillage-stubble effects on overwinter moisture conservation in the semi-arid, chinook-dominated area of southern Alberta. Soil and Tillage Research 29:59-70.

Naeth, M. A., AND D. S. Chanasyk. 1995. Grazing effects on soil water in Alberta foothills fescue grasslands. Journal of Range Management 48:528-534.

Naeth, M. A., and D. S. Chanasyk. 1996. Runoff and sediment yield under grazing in Foothills Fescue Grasslands of Alberta. Water Research Bulletin 32:89-95.

NefF, E. L. 1980. Snow trapping by contour furrows in south-eastern Montana. Journal of Range Management 33:221-223.

Pluhar, J. J., R. W. Knight, and R. K. Heitschmidt. 1987. Infiltration rates and sediment production as influenced by grazing systems in the Texas Rolling Plains. Journal of Range Management 40:240-243.

RIES, R. E., AND J. F. POWER. 1981. Increased soil water storage and herbage production from snow catch in North Dakota. Journal of Range Management 34:485-488.

SAS InstituTE Inc. 1999. SAS/STAT Users Guide. Version 8. Cary, NC: SAS Institute Inc. $2552 \mathrm{p}$.

Willms W. D., J. F. Dormaar, and G. B. Schaalue. 1988. Stability of grazed patches on rough fescue grasslands. Journal of Range Management 41:503-508.

Willms W. D., S. Smoliak, and J. F. Dormaar. 1985. Effects of stocking rate on rough fescue grassland vegetation. Journal of Range Management 38:220-225. 